\title{
PARAMEDIAN FOREHEAD FLAP FOR RECONSTRUCTION OF THE NOSE
}

\author{
Al Hafiz, Effy Huriyati, Bestari J. Budiman, Jacky Munilson
}

\begin{abstract}
Abstrak
Penutupan defek yang ditimbulkan akibat operasi di daerah kepala dan leher umumnya dapat dilakukan dengan penjahitan langsung. Untuk defek yang lebih luas, atau apabila metode penjahitan langsung tidak memungkinkan untuk dilakukan, maka dapat digunakan flap kulit. Laporan kasus ini bertujuan untuk mendemonstrasikan ke ahli THT-KL, bagaimana forehead flap dapat memperbaiki estetika dan fungsi hidung pada kasus deformitas hidung. Satu kasus deformitas pada hidung, seorang laki-laki berusia 69 tahun dengan riwayat basalioma di daerah hidung. Pada pasien dilakukan rekonstruksi hidung dengan menggunakan forehead flap. Rekonstruksi hidung menggunakan forehead flap dapat mengurangi defek pada deformitas hidung. Diperlukan analisis wajah terutama daerah hidung untuk menentukan jenis dan posisi dari flap kulit yang tepat.
\end{abstract}

Kata kunci: forehead flap, deformitas hidung, rekonstruksi hidung

\begin{abstract}
A Defect following head and neck surgery can often be closed using the technique of direct suture. For larger defects or in situations where direct suture is neither applicable, surgical defect in the head and neck especially at the nose, can be filled by local skin flaps. The case was reported in order to demonstrate to Otorhinolaryngology Head and Neck surgeons on how the forehead flap could restore the aesthetic and function of the nose in nasal deformity case. One case of the nasal deformity was reported in a 69 years old man with history of basal cell carcinoma on the nose. This patient was managed using the forehead flap for nasal reconstruction purpose. The employment of this technique could reduce the defects of nasal deformity. Facial analysis particularly nasal area is necessary to determine the exact kind and position of skin flap.
\end{abstract}

Keywords: forehead flap, nasal deformity, nasal reconstruction

Affiliasi penulis : Bagian THTL-KL Fakultas Kedokteran Universitas Andalas, Korespondensi : Al Hafiz, Bagian THTL-KL Fakultas Kedokteran Universitas Andalas,Jl.Perintis Kemerdekaan No.94 PO BOX 49 Padang 25127, email : hafizdjosan_md@yahoo.com, Telp\HP: 08126777076 


\section{INTRODUCTION}

The repair of nasal defects is the oldest form of facial reconstructive surgery. The first recorded account was in 1500 BC when in India, Prince Lakshmana deliberately amputated the nose of Lady Surpunakha. King Ravana arranged for the reconstruction of Lady Surpunakha's nose by his physicians, documenting one of the earliest accounts of nasal reconstruction. Shusuruta Samita, in approximately 700 BC first detailed description of nasal reconstruction. Involved use of a cheek flap, performed by caste of potters in India ${ }^{1-3}$.

Reconstruction of nasal has evolved significantly from early, rudimentary attempt to provide covering for large nasal defects. The defects may result from trauma, tumour resection, prior aesthetic rhinoplasty, and congenital deformities. When planning for reconstruction of distorted or missing tissues of the nose, the surgeon should consider both aesthetic and function ${ }^{1,4}$.

When primary wound closure cannot be performed, cutaneous flaps harvested from the nasal skin may be an alternative for repair of centrally located nasal skin defects that measure up to 2,5 $\mathrm{cm}$ in greatest dimension ${ }^{5}$. Nasal cutaneous flaps are particularly useful for elderly patients because their skin is lax and mobile ${ }^{5,6}$. Skin flap for nasal deformity have the advantage of color, texture, and thickness similar to those of the missing skin of the defect. Choices among the many flaps available would depend on the area of the nose to be reconstructed and the secondary deformity that will be formed ${ }^{6-8}$.

Paramedian forehead flaps are the most preferred local flap for resur- facing large nasal defects. The pedicle flap that most commonly used on the nose is the paramedian forehead flap. Its base lies close to the defect, between the medial brow and medial canthus. The success of this flap would depends on the preservation of it's vascular pedicle, the supratrochlear artery, and the thinning of the subcutaneous tissue from the distal flap before suturing it into the wound ${ }^{9,10}$.

The purpose of this report was to improve the knowledge and was aimed to demonstrate the benefit of paramedian forehead flap for reconstruction of the nose to the Otorhinolaryngology Head and Neck surgeon as skin flap and free graft could restore the aesthetic and function of the nose in nasal deformity.

\section{CASE PRESENTATION}

In January $21^{\text {st }} 2012$, a 69 years old man was consulted from Oncology ENT-HNS subdepartment with diagnosis of nasal tip tumour with suspect of basalioma. Patient was prepared for wide excision in general anesthesia. Initially he complained a mole at his nose tip about 5 years prior to admission. He presented with a $3 \times 2 \mathrm{~cm}$ ulceration of the nose tip. The history revealed that the lesion had gradually increased in size over several months, but did not cause any discomfort or pain. He denied any complaint like fever or headaches. The lesion was easily bled with necrotic tissue, seen redness, and no swelling (figure 1). Cartilago and bone did not seem exposed. There were no abnormality of ear, oral cavity and throat detected during physical examination. No enlargement of cervical lymph nodes. The laboratory results were normal. 
The result of consultation from Internal Medicine Department, there was a mass of the nose, suspected with basalioma, and no contra indication for surgical intervention in general anesthesia for this patient. We also consult to Pathologic Anatomy department, as Oncology and Plastic Reconstructive subdepartment prepared for nasal reconstruction with the forehead flap and frozen section.
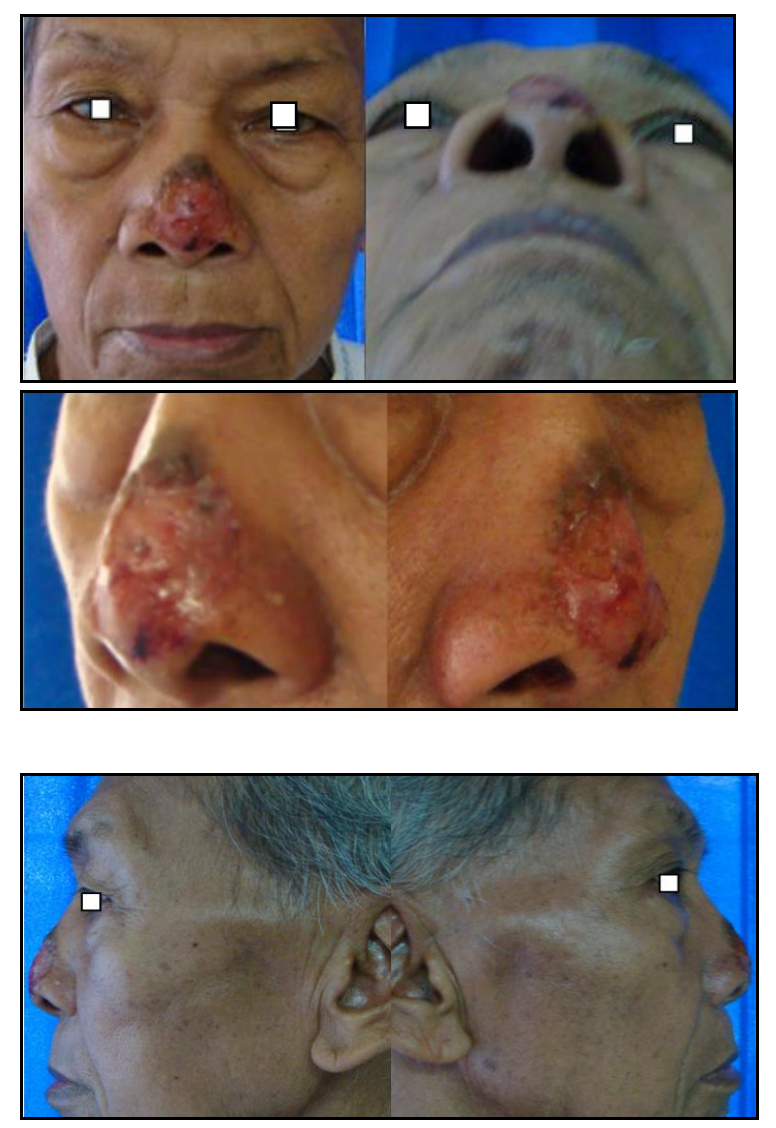

Figure 1. Before surgery

The forehead flap is a 2-stages procedure, and the patient had received preoperative counseling for this condition. Pre-operative preparation, whole blood and packet red cell are prepared for possible bleeding during surgery procedure. One day prior to surgery, 1 gram of Ceftriaxone was given intravenously.
In January $26^{\text {th }} 2012$, surgical excision was performed. One percent Lido-caine with 1:200.000 concentration of epinephrine was injected into the skin surrounding the surgical defect and all the skin of the forehead, except near the pedicle base. The skin incision was made along $3 \mathrm{~mm}$ from the margin of tumour. Moh's micrographic surgery (MMS) was performed in surgical excision of the tumour, followed by repeated tissue sampling along lateral and deep margins. These tissue samples were immediately examined under frozen section control for evidence of tumour.

The result was suited with basal cell carcinoma appearance. We took the sample of tumour for the second time, extended about $2 \mathrm{~mm}$ from margin of tumour. Totally we had taken about 5 $\mathrm{mm}$ of the tumour sample until we got samples with free margin of tumour.

Complete excision with a left paramedian forehead flap reconstruction was performed. A laterally based frontalis muscle flap was pulled, with its attachment to the galea aponeurotica, and rotated to cover the forehead defect. The fat's layer was removed from distal flap. Flap was then sutured at recipient site with interruptured suture technique.

Surgical wound was closed layer by layer. Outer skin layer was closed by using 5.0 prolene threads. Post-

operative therapy, the patient was given intravenously of ceftriaxone 2x1 gram, analgetic tramadol drip $100 \mathrm{mg}$ in 500 $\mathrm{mL}$ of ringer lactat's fluid. Tramadol infusion drip was only administered for one day, and then it was replaced with $500 \mathrm{mg}$ oral mefenamic acid which given for three times a day. 
The first post-operative day, wound was seemed well. No active bleeding. Donor skin color changed into brownish (figure 2). A sensitivity test on the patient's nose with a cotton swab was performed, and the patient can still feel the cotton.

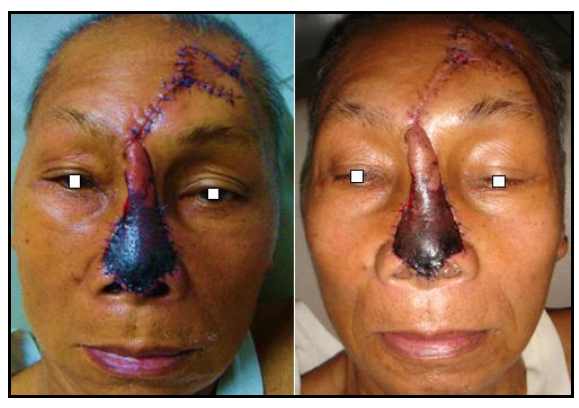

Figure 2. $1^{\text {st }}$ and $4^{\text {th }}$ day post-surgery

As patient was having discharged on the day 7 after surgery, he was treated with oral antibiotic therapy, ciprofloxacin 2x500 mg.

Five weeks (March $9^{\text {th }}$ 2012) after initial flap transfer, the pedicle was divided under local anesthesia. One percent lidocaine with 1:200.000 concentration of epinephrine was injected into thesubcutaneous tissue circumferentially. The nasal skin surrounding the defect superiorly is undermined for a distance of approximately $1 \mathrm{~cm}$. The base of the pedicle was put back to the donor site (figure 3).

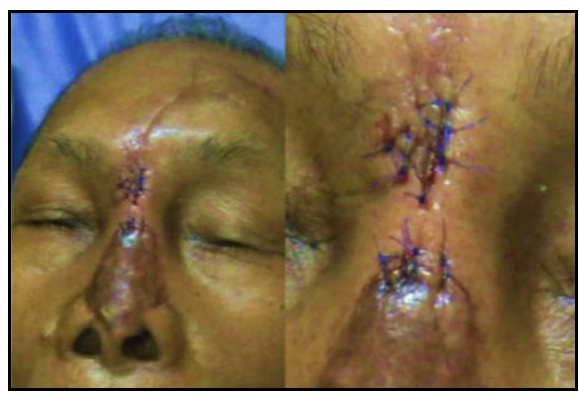

Figure $3.5^{\text {th }}$ week postoperative
Eight weeks after surgery, the patient had control to ENT outpatients. The surgical wound was seemed good (figure 4). Patient still have to control to the oncology subdivision, to detect the recurrence of basalioma.
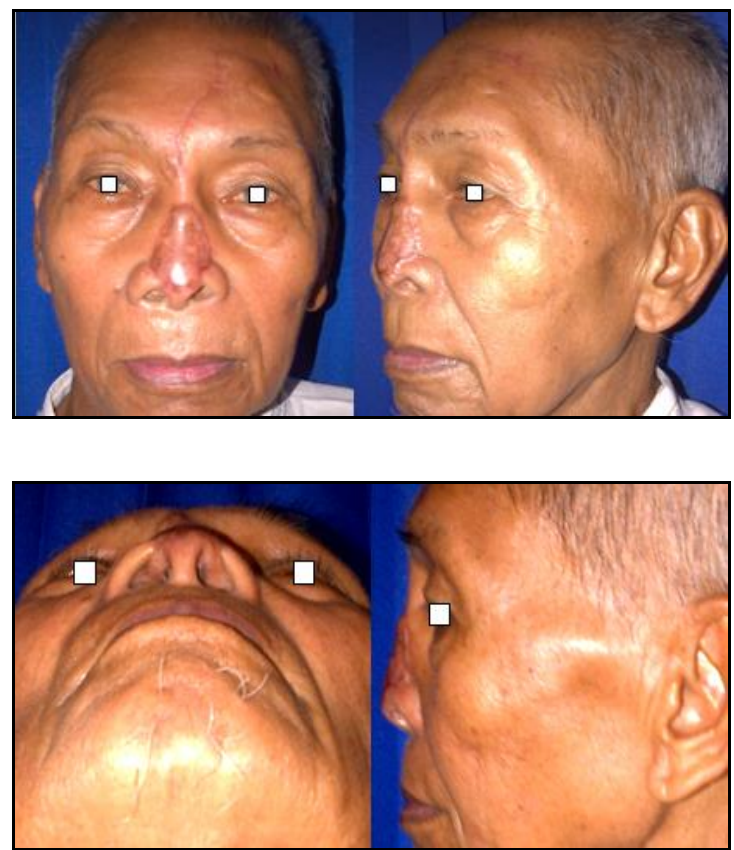

Figure 4. $8^{\text {th }}$ week postoperative

\section{DISCUSSION}

Skin cancers have become significant health problem and their incidence keeps rising each year. In USA melanoma and nonmelanoma skin cancers account for almost $50 \%$ of all cancers diagnosed. Basal cell carcinomas (BCC) account for approximately $80 \%$ of all nonmelanoma skin cancers diagnosed ${ }^{4,11}$.

The BCC arises from pluripotential cells within the epidermis or hair follicles. BCC's predilected areas are most commonly identified on the sun-exposed area, with the head and neck accounting for 85 to $93 \%$ of all cases, and $25 \%$ of which are found on the nose ${ }^{11,12}$. This 
tumour is more common in men than in women, and is most frequently seen in individuals between 40 and 70 years of age $^{4}$. In this case, patient was 69 years old and his occupation is a farmer for more than 50 years. Ultraviolet A (UVA) is able to potentiate the direct effects of ultraviolet B (UVB) on skin cell DNA. UVC is a potent carcinogen, but is filtered by ozone ${ }^{11}$. In addition to environmental factor, premalignant lesion, sebaceous naevus at the nasal tip presented since 5 years before hospital admission could be another factor that contribute to the occurrence of BCC in this patient ${ }^{12,13}$.

Nose is a complex structure which gives character to the face. The external nose consists of discreet aesthetic subunits including the dorsum, the sidewalls, the ala, the soft-tissue triangles, and the tip ${ }^{1,14}$.

There are several types of $\mathrm{BCC}$; nodular (45-60\%), superficial (15-30\%), pigmented (10-20\%) and morphoeic type ( $9 \%)$. Superficial types, the lesions often seen in multiple patches, contained with no dermal invasion, may have shallow ulcer, atropic scar or crusting. In this patient, we did not find any invasion of the carcinomas to the muscle or cartilage of the nose ${ }^{11,12}$.

MMS was developed in 1932. MMS is a process of initial surgical excision of the tumour, followed by repeated tissue sampling along lateral and deep margins. These tissue samples are examined immediately under frozen section control for evidence of tumour. This process is repeated until clarity of tumour is finally obtained. In this patient, we performed twice, until we got the sample which free margin of the tumour $^{13,15}$.
There are several modalities available for BCC treatment. First, surgical excision involves the fullthickness removal of the lesion, down to subcutaneous fat, along with the rim of normal tissue. With the use of MMS, cure rates of primary $\mathrm{BCC}$ and recurrent BCC could reach 99\% and 93-98\% respectively. An additional treatment after surgical therapy is cryotherapy. Prior to cryotherapy, local anesthesia was used and the lesion was rapidly frozen with liquid nitrogen ${ }^{11,12}$.

The paramedian forehead flap has become the standard of care for major nasal reconstruction. The classic prosedure involves a second-stage operation to devide and inset the external pedicle ${ }^{16}$. According to Park, this technique is used for reconstructing of nasal defects $>1,5$ centimeters in diameter ${ }^{17}$.

The forehead flap is commonly a two stages procedure, and patients should receive preoperative counseling concerning their appearance between the first and second stages of the procedure. Thorough preoperative planning, including assessment of the defect, hairline height, and forehead laxity, is important. Patients should be given wound care instruction, and realistic goals about the final outcome of their nasal reconstruction ${ }^{5}$. According to Nicolas et al report ${ }^{18}$ they experienced in 16 patients with a three-staged forehead flap. First stage was performed to transfer the forehead flap on the nose, second stage was performed to attenuate the pediculized forehead flap (day 15) and third stage was done to divide the pedicle (day 30). This threestage procedure improves the quality of the final aesthetic result. But, this 
refinement must not be excessive because of the risk of necrosis ${ }^{18}$.

The pedicle detachment could be done in local anesthesia. The anesthetic was injected into subcutaneous tissue plane because this is the location of the nerves and vesels supplying the forehead skin ${ }^{19}$. We performed the second stages procedure of this patient after 5 weeks. Baker said the schedule for pedicle detachment approximately 3 weeks following the date of initial flap transfer ${ }^{5,19}$. Although the pedicle may be safely devided 2 weeks after surgey, the shorter interval may limit the ability of pedicle to attenuate the more proximal flap remaining at the recipient site when the flap is to be inset ${ }^{5,19}$.

Based on the source of supratrochlear artery, forehead flap devided into median forehead flap, midline (median) forehead flap and paramedian forehead flap (figure 5) ${ }^{13,19}$. We choosed a paramedian type to decrease trauma of donor-site, especially supratrochlear artery's that might get injured during the procedure.

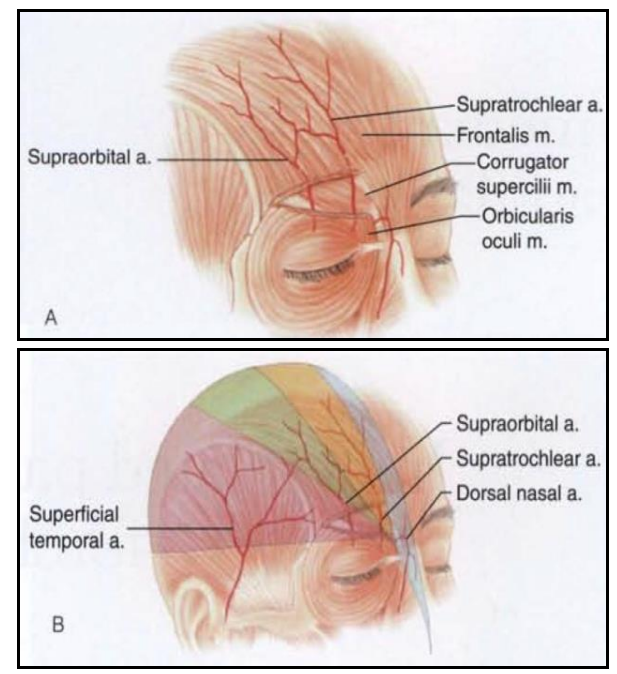

Figure $5 \mathbf{a} \& \mathbf{5 b}$. Vascular territories of arteries supplying forehead skin $^{19}$
According to Park $^{8}$, forehead flap is the flap of choice for large cutaneous nasal defects because it is characterized by many of virtues of a regional cutaneous flap ${ }^{1}$. There is abundant tissue allowing resurfacing of the entire nasal unit with a single flap ${ }^{2}$. It follows the principle of replacing tissue with sort of tissue having similar characteristic with texture and nose colour ${ }^{3}$. There is acceptable donor sight morbidity due to this procedure ${ }^{4}$. The flap has proven to be extremely robust and dependable, even in individuals with small-vessels disease. The primary disadvantage of the procedure is the need for additional stages and the fact that the pedicle is cumbersome and requires continued wound care for a long postoperative period. Another disadvantage of the paramedian forehead flap is the vertical forehead scar. The wound edges must be carefully estimated to minimize wound tension ${ }^{5,8,20}$.

Complication of nasal reconstructtion using the local flap, may occur early or late in the postoperative course. Early complications include bleeding, infection, and flap necrosis. Meanwhile, scarring, nasal airway obstruction, cutaneous pigmentary abnormalities, and vascular abnormalities are late complication 5,20,21.

For hemorrhage, external bleeding may occur due to the exposed borders of interpolated forehead flap. Cauterizing the margin of pedicle at the time of flap transfer is helpful in reducing postoperative bleeding. However, the pedicle usually produces oozes blood intermittently for 12 hours following flap transfer. Persisten bleeding beyond this period can be controlled with localized compression or by cautery 20,21 . 


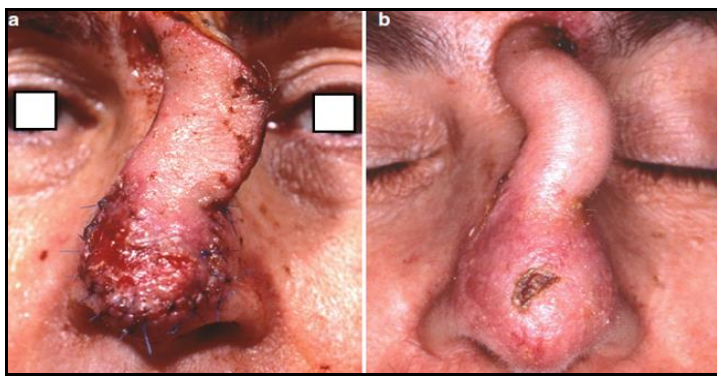

Figure $6 \mathbf{a} \mathbf{\&} \mathbf{6 b}$. Epidermolysis of paramedian forehead flap ${ }^{21}$

In partial thickness flap necrosis (epidermolysis), debridement and antibiotics therapy are not necessary. If epidermolysis occurs in interpolated forehead flap, devided of the flap is delayed until wound healing is completely achieved (figure 6) ${ }^{21}$. Another case, like in a wide necrotic flap, a second cutaneous flap to provide cover is required ${ }^{20,21}$.

\section{REFERENCES}

1. Park SS. Nasal Restoration with Flaps and Grafts. In: Bailey BJ, Johnson JT, et al editors. Otolaryngology Head and Neck Surgery, $4^{\text {th }}$ Ed. Philadelphia: Lippincott Williams \& Wilkins, 2006: p. 2422-53.

2. Monhan N, Wise J. Local \& Regional Flaps in Head \& Neck Reconstruction. In: Lalwani AK, editor. Current Diagnosis \& Treatment in Otolaryngology Head \& Neck Surgery. New York: McGrawHill Medical, 2008: p. 923-30.

3. Becker D, Guyuron B. Nasal Reconstruction and Aesthetic Rhinoplasty. In: Siemionow MZ, Eisenmann $M$, editors. Plastic and Reconstructive Surgery. London: Springer, 2010: p.313-24.

4. Thomas JR, editors. Cummings Otolaryngology Head \& Neck Surgery. 5th Edition. Philadelphia: Mosby Elsevier, 2010: p.364-72.

5. Boyd CM, Baker SR, Fader DJ, Wang TS, Johnson TM. The Forehead Flap for Nasal Reconstruction. Arch Dermatol 2000: 136(11);1365-70.
For incomplete excision of BCC cases, there are still controversies about the best form of treatment for them. From Georgeu ${ }^{11}$, Rowe et al, found that $50 \%$ of cases were recur in the first two years, and $66 \%$ of cases were recur in the first three years. Therefore, the option in the elderly with an incomplete excision may be regular follow up or to refer the patient for local radiotherapy ${ }^{11,12}$.

\section{CONCLUSION}

This report demonstrated the benefit of paramedian forehead flap for reconstruction of the nose to the Otorhinolaryngology Head and Neck surgeon, as skin flap and free graft could restore the aesthetic and function of the nose in nasal deformity.

6. Gilbert RW. Free Flaps in Head and Neck Reconstruction. In: Gleeson M, Browning GG, Burton MJ et al editors. Scott-Brown's Otorhinolaryngology Head and Neck Surgery. $7^{\text {th }}$ Edition. London: Edward Arnold, 2008: p. 2868-90.

7. Watkinson JC, Gilbert RW. Pedicled Flaps in Head and Neck Surgery. In: Gleeson M, Browning GG, Burton MJ et al editor. ScottBrown's Otorhinolaryngology Head and Neck Surgery. $7^{\text {th }}$ Edition. London: Edward Arnold, 2008: p. 2847-66.

8. Park SS. Local and Regional Cutaneus Flaps. In: Paper ID, John F, Holt GR, et al. Facial Plastic and Reconstructive Surgery. $2^{\text {nd }}$ Edition. New York: Thieme, 2002: p. 528-48.

9. Salgarelli $A C$, Bellini $P$, Multinu $A$, Magnoni $C$, Francomano $M$, Fantini $F$ et al. Clinical Study, Reconstruction of Nasal Skin Cancer Defects with Local Flaps. Journal of Skin Cancer, 2011: 1155; 1-8.

10. Raghavan $U$, Jones NS. Nasal Reconstruction. In: Gleeson M, Browning GG, Burton MJ et al editor. Scott-Brown's Otorhinolaryngology Head and Neck Surge- 
ry. $7^{\text {th }}$ Edition. London: Edward Arnold, 2008:3015-27.

11. Georgeu GA, Gleeson M. Skin Cancer of the Head and Neck. In: Gleeson $M$, Browning GG, Burton MJ et al editor. ScottBrown's Otorhinolaryngology Head and Neck Surgery. $7^{\text {th }}$ Edition. London: Edward Arnold, 2008: p. 2395-405.

12. Hubert DM, Chang B. Basal Cell and Squamous Cell Carcinoma. In: Kryger ZB, Sisco M, editors. Practical Plastic Surgery. Texas: Landes Bioscience, 2007: p. 126-30.

13. Pernas FG, Resto V. Principles of Nasal Reconstruction after Mohs Micrographic Surgery. Department of Otolaryngology, University of Texas Medical Branch. Grand Rounds Presentation, March 31, 2010.

14. Stucker FJ, Pou JW, Nguyen TV. Surgical Anatomy of the External Nose. In: Stucker FJ, de Souza C, Kenyon GS, Lian TS, Draf W, Schick B, editors. Rhinology and Facial Plastic Surgery. Berlin: Springer, 2009: p.695-9.

15. Jewett BS, Baker SR. History of Nasal Reconstruction. In: Baker SR, editor. Principles of Nasal Reconstruction. New York: Springer, 2011. p.3-13.
16. Fudem GM, Montila RD, Vaughn CJ. Singlestage Forehead Flap in Nasal Reconstruction. Annals of Plastic Surgery. 2010: 64(5);645-8..

17. Park SS. Reconstruction of Nasal Defects Larger Than 1,5 Centimeters in Diameter. Laryngoscope. 2000: 110(8);1241-50.

18. Nicolas J, Labbe D, Soubeyrand E, GuillouJamard MR, Rysanek B, Compere JF, Benateau H. Nasal Reconstruction with $A$ Three-staged Forehead Flap: Assessment of 16 cases. Rev Stomatol Chil Maxillofac, Feb 2007: 108(1); 21-8.

19. Baker SR. Interpolated Paramedian Forehead Flaps. In: Baker SR, editor. Local Flaps in Facial Reconstruction, 2nd Edition. Michigan: Mosby Elsevier, 2007: p.265-72.

20. Little SC, Hughley BB, Park SS. Complications with Forehead Flaps in Nasal Reconstruction. Laryngoscope, June 2009: 119(6);1093-9

21. Naficy S, Baker SR. Complications and Management. In: Baker SR, editor. Principles of Nasal Reconstruction. New York: Springer, 2011. p.413-56. 